\title{
(W)riting and (de)scribing martyrdom: The church's construction of Manche Masemola
}

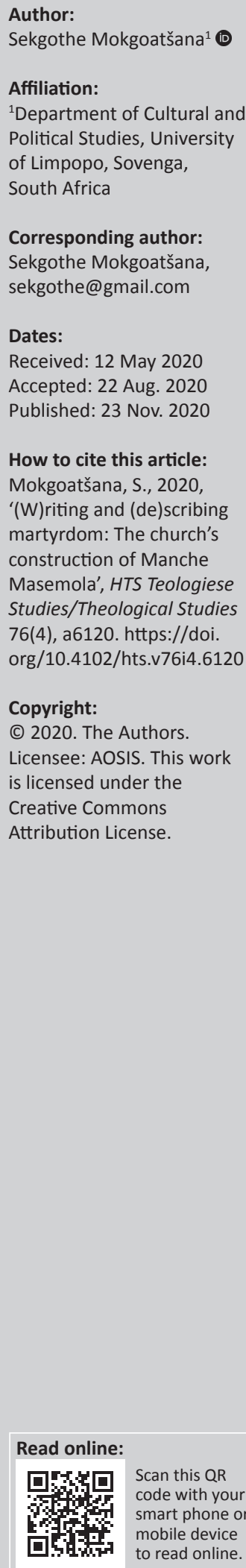

The purpose of this article is to describe how the Manche Masemola narrative crafts and constructs her as a martyr; dying in defence of her faith in the face of fierce religious competition between her Sepedi culture and Anglican faith. Manche is constructed as an extraordinary person who symbolises Virtue, battling with Vice. This article will examine Manche's personality, and how the various commentators put her against unbearable conditions which only an extraordinary person can face. Tropes of torture, sacrifice and persecution will receive attention as instruments to construct martyrdom. This article will use primary and secondary data available to collect data. Data will be broken into themes and analysed using a narrative method.

Contribution: This article continues a long debate of martyrdom and sainthood. It probes further the polysemous nature of martyrdom, its complexity, as well as the politics that go with it.

Keywords: Manche Masemola; martyrdom; martyr; torture; persecution; sacrifice.

\section{Introduction}

Manche Masemola has been declared a martyr of the Anglican, a black young teenager in the rural Sekhukhuneland to die for her faith. Her grave became a shrine around which many pour their tears, worship and celebrate her since her death. According to Russel Molefe, she was canonised as a saint of the Anglican Church in 1975 and her statue was erected in Westminster, London, in 1998, whilst the Limpopo provincial government built a monument in her village of GaMarishane, as reported in Kgopelo (2017:12). Manche Masemola has become a shrine that attracts the attention of the world, and this celebration is associated with her arduous life to defend her faith. This celebration began 7 years after her death:

In 1935 a little group of Christians made a pilgrimage to the grave. Another followed in 1941; a third in 1949. In 1969 her mother was baptized into the church. In 1975 the name of Manche Masemola was added to the calendar of the Church of the Province of Southern Africa. Now, hundreds visit the site every August. (Westminster Abbey 2019)

The decision to declare her martyr arose in 1937 after Bishop Wilfred had interviewed Lucia, almost 10 years after Manche's death. Whereas many sources (Goedhals 1998, 2000; Higham 1937; Mokgoatšana 2019a; 2019b; 2019c) speak of her as a martyr, none of these sources devoted their attention to how she acquired martyrdom. It is in the interest of this article to explore the various strategies used to consecrate her as a martyr.

Circa 1928, Manche Masemola died in the face of conflict between colonial, theological and imperialism and resistance in Sekhukhuneland. Her death is shrouded in mystery and contradictions. Her tale represents a chronicle of a martyr whose exploits to resist colonial domination are less reported. In addition, she is described as a martyr, but no explanation is given on how the narrative of martyrdom is achieved. The purpose of this article is to explain how the Manche Masemola narrative uses strategies of torture, persecution and sacrifice to construct martyrdom. Like most hagiographies, her narrative is told to inspire courage, admiration and reverence. Its purpose is to use Manche as a model worthy of emulation by young Christian converts. In this essay, I shall provide the strategies employed in the narrative to achieve martyrdom for Manche Masemola. Firstly, the image of blood is invoked to create a representation of the sacrificial object, which has to be offered to the higher-order to receive an eternal reward of life. Secondly, Manche's body is subjected to inhuman physical torture, which places her to

Note: Special Collection entitled Social Memory Studies, sub-edited by Christina Landman (UNISA) and Sekgothe Mokgoatšana (UL). 
choose between victory and surrender, and lastly, explore the theme of sacrifice and how it is important to elevate the legendary Manche to the level of saints.

\section{Martyrdom}

A martyr is someone who suffers persecution and death for advocating, renouncing, refusing to renounce or refusing to advocate a belief or cause as demanded by an 'external party' (Gölz 2019:5; cf. Wikipedia 2020, 'Martyr'). The MerriamWebster Dictionary (2009) defines a martyr as (1) a person who voluntarily suffers death as the penalty of witnessing to and refusing to renounce religion, (2) a person who sacrifices something of great value and especially life itself for the sake of principle, (3) victim, a great or constant sufferer.

Central to these dictionary definitions, a martyr has to suffer a bodily pain that may result in eventual death. A martyr has to profess a set of beliefs, a faith or political view which he or she has to defend even under severe persecution. To be a martyr is to be a sufferer, a victim who is prepared to suffer and attain the ideal freedom to hold his or her own views, and to defend them for others to enjoy even after his torments or death. De Soucey et al. (2008:100) contend that martyrs are seen as 'posthumous charismatic' personalities; and that these qualities are assumed after death. They are invoked through celebrations long after their lives. Because they represent an ideal, martyrs are polysemous symbols whose interpretation is defined by establishments. Kassmir (1991:6-7) proposes criteria which should be used to judge whether a character is considered a martyr or not. I will use these criteria in conjunction with the criteria determined from the definitions of a martyr to determine whether Manche indeed would qualify as a martyr. These criteria are:

1. That the victim died because he or she was a Christian, that is, one's religious self-identification, or the religious identification made for one by the powers that be, determined the victim's status as a martyr.

2. The second criterion, which is really a stronger version of the first, includes the element of choice. A martyr is one who is given the opportunity to recant the faith in order to save one's life and chooses not to recant.

3. The nature of Christian life the character led.

In terms of these criteria, to be a martyr means to die for one's faith or religious convictions; to die defending a particular religious position. Manche's life should be interpreted along with these criteria for a fair justification. Something important about martyrdom is the motive of the victims that they have intended to face the consequences for their choice. This volitional act, according to De Soucey et al. (2008), makes an interesting point:

[I]nasmuch as martyrdom involves actively opting for death rather than abandoning a belief, the martyr publicly embraces a political, ideological or religious position that puts him or her in opposition to powerful institutions. (p. 101)
Like most martyrs, Manche Masemola is linked to a set of beliefs that she is prepared to die for. Indeed, Manche is believed to have died for her faith, and in addition, she is persecuted, yet sticks to her faith till her eventual death. In examining her construction as a martyr, I will, in addition to the criteria proposed in the preceding discussion, include themes of persecution and torture, sacrifice and commitment.

\section{Constructing Manche Masemola as martyr}

I want to subject Manche Masemola to the proposed criteria for martyrdom and justify the assumption that she died as a young, female martyr of Sekhukhuneland. The whole narrative of Manche Masemola describes a journey of a fragile teenager who battles with the family to defend a faith foreign to the community, and difficult to comprehend because its teachings were antithetical to Bapedi culture. Traditions of the new religion are radically opposed to Bapedi practices of initiation schools, marriage customs and practices, as well as a mere mode of dress. This new faith's teachings of celibacy and recruitment to the Wayfarers as a stepping stone to become nuns (Daughters of Mary) need someone very strong as Manche to be able to defend such queer traditions and practices.

The whole narrative is littered with epithets and references to death. Manche is the central figure of the 'death themes' and sub-plots. In Lucia's testimony (Parker 1937), the following expressions dominate the discourse:

1. '... when we die we go to God'.

2. 'I shall be baptized with my own blood'.

3. 'They went on beating her until she drank the stuff. Then she died'. (pp. 1-2)

These expressions point to Manche's commitment to the Church against all adversaries. She was committed to her faith despite all the beatings, threats and severe corporeal bruises. Death seems to be an eventual destiny targeted; this is evident in her words, 'what I will not do is to turn away from the Church'. This statement expresses Manche's desire to die for her faith. According to Kuzwayo (2013:32), 'the more Manche grew in her faith, the more disappointed her parents became, and her mother tried to spear her and set her on fire, but she ran away' (Kuzwayo 2013:41). She makes a public announcement of her faith, embraces it and makes a choice to face ridicule or persecution. In the face of torture, Manche maintains that 'what I will not do is to turn away from the church' (Goedhals 2000:104; Kuzwayo 2013:38). This statement is the bedrock of Manche's faith. All bodily punishments and threats could not sway her away from her ambition to go to God. Her Christian character, a way of life she had designed for herself, is evident in her daily practice; praying every day at the 'kopje' after they had taken her clothes away (Masenya 2017b:18). The narrative extols Manche for fighting against forces of 'darkness'. Despite not having been baptised as the Church wished, she transmogrified and died a good death, which later in life declares her as a martyr and saint. As a female martyr, 
Manche pursues an altruistic expedition to self-sacrifice. She is aware of her fallibility, her frailty and defencelessness, yet she commits to acts of defiance to hold onto her faith. She is painted as a blameless character whose death unites the church and calls to action the planting of more seeds of the church than before. According to Masenya (2017a:14), 'Manche's narrative presents a unique case of a faith commitment by a young rural girl'.

Like all martyr narratives, the Manche Masemola narrative centres on the image of an ordinary person willing to accept death and extraordinary pain. As a teenager and female member of the society, she has no standing before the community in which she was born. All her rights as a child and woman are subordinated to cultural rights that privilege men to have a voice and juridical power. Despite lack of this power, Manche Masemola is able to stand out, act with resilience and guts to defend her chosen faith. The story portrays a relentless urgency for the vulnerable and feeble to seek the life of heaven.

\section{Sacrifice and commitment}

The idea of sacrifice is rooted in many old traditions. There is no universal definition of the concept, making the ethos and practices of ceremonial action diverse and sometimes interlinked. There are some elements, which can be used to interpret the concept of sacrifice; caution, that these elements are not exhaustive, and do not constitute the whole field of sacrifice. These elements are, but not limited to, gifts, meals, expiations and cosmogonic rites.

According to Smith and Doniger (1989:189), sacrifice is defined as the act of giving up something in order to receive something of greater worth. The idea of sacrifice is closely linked with expiation, and propitiation; the offering of the body, or blood as a symbol of commitment to faith, or thanksgiving. The ritual of sacrifice is a symbolic communication of the ideas of the sacrifice, who subjects his or her life to torture, and terror hoping to gain rewards of immeasurable worth.

The story of Manche Masemola is a difficult journey of selfsacrifice. As soon as she accepted to join the Wayfarers, she was on a straight path to becoming one of the Daughters of Mary. Such a decision would inevitably cause conflict between her and her parents. This enraged her parents who regularly thrashed, and her response had always been 'neither death nor life would turn her away from the church' (Parker 1937:2). These words are a statement of faith, a commitment to face all odds in the name of religious belief.

Manche is consciously constructed as a fearless character who stands between her traditional cultural beliefs and her new spiritual faith. She is constructed to face adverse conditions and withstand them. In the narrative, the central theme of the story is how she was tortured by her parents. She is beaten so regularly that it sounds incredible that a 13/14-year-old can hold so steadfastly to her faith.
Manche is gifted with the extraordinary human capacity to face murderous conditions. Winstead (2005:201) proposes that fear - its absence in the martyr, its presence in the reader-operated as a mechanism of social control, anticipating and forestalling radical imitatio amongst increasingly broad audiences. It is constant beatings, threats and the brandishing of the firebrand, which all do not deter her from leaving her faith. Sacrifice offers a compelling story because of the high value placed on an individual's life. She chooses to make her own decisions; thus walking the tightrope instead of just conforming to what her peers subscribe to.

Her parents would, without doubt, have fears of the new, encroaching religion with its dangers of eroding an African culture shaped by an African world view. Firstly, she would be denied to continue with her newfound faith. Secondly, she has Father Moeka, who also stands on her way to making an informed choice about how she would like to dress for their baptism.

Sacrifice offers a compelling story because of the high value placed on an individual's life. Martyr narrative centres on the image of an ordinary person willing to accept death and extraordinary pain. Death and pain in the hands of institutional opposition make violence with the martyr's body and subsequent reputation operate as a tool for reputational agents and audiences, giving a sacrifice of life resonance that it would not otherwise possess. DeSoucey et al. (eds. 2008) make a very interesting point about martyrs when they proclaim:

$[I] \mathrm{n}$ as much as martyrdom involves actively opting for death rather than abandoning a belief, the martyr publicly embraces a political, ideological or religious position that puts him or her in opposition to powerful institutions. (p. 101)

Moeka was concerned about the persecution suffered by the catechumens he was preparing for baptism, to the extent that he advised them not to go against their parents' wishes. He records that Manche in response to this said to him, 'If they cut my head, I will never leave my faith' (Goedhals 1998:38) and she went on to claim that she would be baptised with a 'better baptism' (Goedhals 1998:38). Lucia recalls her saying, 'I shall laugh the more they hurt me' (Goedhals 1998:38). Courageous words indeed, which reflect a sense of determination to hold on to what one believes in. Manche's repeated claim that she would be baptised with her own blood could be viewed either literally or figuratively, as nobody can really tell what she meant or understood by that (Kuzwayo 2013:53). This claim, which Mokgoatšana (2019c:4) describes as a prophecy based on a myth, is the source from which Manche's martyrdom was constructed. In essence, these words are quoted out of context because Manche exclaimed when Moeka was reluctant to baptise her. When Moeka openly told her that she would not be baptised, she answered, "Then I will be baptised with my own blood!' (Parker 1937:2) [author's own emphasis]. Her response to Moeka's insistence on western clothing has always been distorted and misinterpreted. Because of their 
hagiographical nature, stories like these tend to conflate history with religious manifestos. Hodgson (1986:146) ascribes Manche's martyrdom to her prophecy.

Sacrifice offers a compelling story because of the high value placed on an individual's life. Martyr narrative centres on the image of an ordinary person willing to accept death and extraordinary pain. As stated by DeSoucey et al. (eds. 2008:101), 'death and pain in the hands of institutional opposition make violence with the martyr's' body and 'subsequent reputation operate as a tool' for 'reputational agents and audiences, giving a sacrifice of life resonance that it would not otherwise possess'. DeSoucey et al. (eds. 2008) make a very interesting point about martyrs when they proclaim that:

[I]n as much as martyrdom involves actively opting for death rather than abandoning a belief, the martyr publicly embraces a political, ideological or religious position that puts him or her in opposition to powerful institutions. (p. 101)

Manche died a terrible death, 'hacked with a machete', 'flogged to death' (Mokgoatšana 2019c:10) and many more unbearable heinous acts acted upon her body and soul. She indeed sacrificed her life for her faith. She made difficult choices in the context of the historical time in question. A teenager choosing to accept a foreign faith, a faith to which she was barely a year, compromising her African religion was a tall order. As a minor, she defied her parents, who served as guardians on her faith; instead, she stood on her own to proclaim a faith. Breaking from the ties of African culture rightly or wrongly, represented a revolutionary act which the church celebrates up to today.

\section{Torture and persecution}

Torture dominates the story of Manche Masemola, foregrounding the subjection of the body to inhuman treatment, violation of a vulnerable child, who becomes a defenceless victim. As soon as Lucia and Manche report to Manche's mother that they wanted to join the catechumenal classes, they receive disapproval. At that moment, the two girls take a stand which is likely to put their lives at risk. In her testimony, Lucia proclaims, 'then we said we would go' (Parker 1937:2). This was the beginning of all trouble. Determined to stop them from attending the church, Manche's mother beat her regularly. The climax of the story is when the mother pursued her with a spear, as the narrative goes. Furthermore, Manche's mother went to the extent of threatening to burn the hut in which Manche was hiding. Both instruments, the speech and fire(brand), would have destroyed her life, subjecting her to gruesome acts of bodily violation and mutilation. On intent alone, the mother's actions had exceeded the bounds of punishment. In African culture, there are limits to which punishment can mete out. Describing this altercation, Mokgoatšana (2019a:11) states that:

[S]etting Manche on fire is very bizarre, to say the least. It is not botho (ethical) or proper to punish a child in this manner, irrespective of how well she has crossed the line in her conduct. Punishment is always done in moderation.
This scene is a precursor to the worst torture to be experienced by a vulnerable child.

Like all witnesses, Manche was subjected to a gruesome, inhuman violation. All testimonies, from Lucia, Elsiena and commentators (Goedhals 1998, 2000; Higham 1941; Hodgson 1986; Manyaka 2017), paint a similar picture of a girl who was beaten ruthless, and so regularly that only an extraordinary person can sustain. Various instruments as sharp as spears, hoes, machete, and a firebrand too; yet, these efforts could not diminish a burning fire of faith in her. Suppression and corporeal punishment could not deter her from accepting her new faith.

In her testimony to Bishop Parker (1937), Lucia explained that:

The thrashings began in October 1927 and went on till March 1928. (There is obviously some mistake here; the Cowley Evangelist Magazine's account written much nearer the time states that Manche died on February 4th; this would seem to agree with Lucia's statement that it was the New Year when the persecutions began to be bad). (p. 1)

It is these beatings that are reported to have finally succumbed Manche to death. Of interest, Manche died a week before her baptism, importantly a week before Easter. Her death is important in religious terms because it is connected in time and space to the death of Jesus. Perhaps other than using the principle of baptismus flamis, this connection was instrumental in declaring Manche a martyr and later a saint. The theme of torture and mortification helps sustain piety, devotion and transfiguration. Sepedi culture is (re)presented as grotesque for religious consumerism. Several narrators describe Manche's killing in callous aphorisms and phraseology. Manche is not only 'beaten to death' but 'hacked' with a machete. The narrators deliberately graft Manche as a helpless victim in the hands of her parents. Her body is a significant marker of religious discourse - signifying courage, leadership and vision. Her body, therefore, becomes a site for defining commitment to faith, and suffering represents the greatest form of sacrifice that characterises conversion and submission. There is further evidence that Mabule, her younger sister, together with Elsiena Masemola witnessed all these acts of intimidation and dehumanisation. What Lucia's testimony does is create an unfriendly, monstrous world where only Manche and her ilk dare to proclaim an ideology, a faith or a conviction without regard to the consequences.

Throughout the narrative, the central theme is torture and persecution. The theme of torture and mortification helps sustain piety, devotion and transfiguration. Sepedi culture is (re)presented as grotesque for religious consumerism. Manche is not only 'beaten to death' but 'hacked' with a machete. Death and pain in the hands of institutional opposition make violence with the martyr's body and subsequent reputation operate as a tool for reputational agents and audiences, giving the sacrifice of life resonance that it would not otherwise possess (eds. DeSoucey et al. 2008:101). 
The version of the spear first appears in Lucia's testimony to Wilfred Parker in 1937. In this testimony, the mother brandishes a firebrand with the hope of burning the hut in which Manche was hiding. No amount of anger would lead a mother to burn her own hut which would need the extensive sacrifice of close members and friends to rebuild. The grain hut as expressed probably refers to the family barn, where supplies of sorghum are kept for current or future use. Destroying one's barn is tantamount to suicide because the future is uncertain, especially in Sekhukhuneland, where the climate is volatile and unpredictable. Goedhals (2000:2) describes the Sekhukhuneland of the 1920s as an area where the climate was harsh. What the narrators do is to paint a graphic sordid, diabolic environment on which Manche lives, and professes her faith. This satanic world where neither neighbour nor relative admonishes Manche's mother for her 'uncouth' manner in which she treats her child is bewildering.

In this world, she was flogged to death and her body sewn up in a blanket, to be hurriedly buried (Higham 1941:252). The source of this testimony is unknown unless collected from an interview. Higham's version should be contrasted against Lucia's testimony as interpreted by Father Moeka to the Bishop of Pretoria in 1937. This version contends that they went on thrashing her and she eventually died. This testimony seems to suggest that Manche not only died of the beatings but drinking the concoction prepared to change her commitment to the Church.

\section{Conclusion}

This article has discussed the various instruments used to craft and construct Manche Masemola as a martyr. Common to most martyrs, Manche included, martyrdom is a product of a group's identification of a figure selected for celebration on the basis of having upheld particular values and having suffered inhuman violation. Manche's martyrdom is centred around her resistance and revolutionary zeal to break from her traditional religion and embracing a new faith. She was physically bruised, tortured and persecuted for her new faith; instead, she was prepared to die for commitment to it, and thus paid with her life.

Manche represents a true religious martyr whose commitment to faith has become a rallying voice for the youth. She has become an inspiration to all and sundry, celebrated annually through an organised pilgrimage which has become a popular collective memory in South Africa, and beyond. This study managed to lay bare how martyrdom is assigned to an individual, and why it is necessary as a model to inspire, and teach particular morals.

Manche's fragility and vulnerability are significant to understand the power of marginality. In her marginal condition, she has become a shrine that binds the erstwhile traditional community with the developing world. As such she is immortalised, and celebrated by the young and old. I can safely conclude that the manner in which Manche's story is constructed crafts Manche as an extraordinary person to withstand the murderous acts of violation to eventually become a heroine. Her story makes tangible the values and beliefs the Church seeks to promote. Future studies may plot dots to connect the archival records and align it to the story as it is told in the community. Manche as a courageous child has become a model for emulation. She will be a good instrument to shape policy on memorialisation; in addition, the role of young people in the construction of identities.

Future studies have multiple windows to study why the Marishane community where Manche was born and buried is always silenced in the telling of the Manche story. Outside the church, there is no effort to establish what the real issues were. Furthermore, the role of oral history and archival records to determine people's lives and livelihoods when the story was constructed would be an interesting story. It would be worthwhile to study youthfulness as the urgency for transforming discourse.

\section{Acknowledgements}

The author wishes to thank the support of the University of Limpopo for the time and resources to complete this article.

\section{Competing interests}

The author has declared that no competing interests exist.

\section{Author's contribution}

I declare that I am the sole author of this research article.

\section{Ethical consideration}

This article followed all ethical standards for carrying out research without direct contact with human or animal subjects.

\section{Funding information}

The author received no financial support for the research, authorship and/or publication of this article.

\section{Data availability statement}

Data sharing is not applicable to this article as no new data were created or analysed in this study.

\section{Disclaimer}

The views and opinions expressed in this article are those of the author and do not necessarily reflect the official policy or position of any affiliated agency of the author.

\section{References}

DeSoucey, M., Pozner, J., Fileds, C., Debransky, K. \& Fine, G.A. (eds.), 2008, 'Memory and sacrifice: An embodied theory of martyrdom', Cultural Sociology 2(1), 99-121. https://doi.org/10.1177/1749975507086276 
Goedhals, M., 1998, 'Imperialism, mission, and conversion: Manche Masemola of Sekhukhuneland', in A. Chandler (ed.), Terrible alternative: Christian martyrdom in the 20th century, pp. 30-45, Continuum International Publishing Group, Limited, Cassel, London. ISBN 978-0-8264-4844-6.

Goedhals, M., 2000, 'Colonialism, culture, Christianity and the struggle fo selfhood: Manche Masemola of Sekhukhuneland, c.1913-1928', Alternation 7(2), 99-112.

Gölz, O., 2019, 'Martyrdom and the struggle for power. Interdisciplinary perspectives on Martyrdom in the modern middle east', Behemoth 12(1), 2-13.

Fields, A., Nort Dobransky, K. \& Fine, G.A., 2008, 'Memory and sacrifice: An embodied theory of Martyrdom', Cultural Sociology 2(1), 99-121. https://doi.org/ $10.1177 / 1749975507086276$

Higham, M.M., 1937, Torches for teachers. Stories, anecdotes, and facts illustrating the Church's teaching, Society for Promoting Christian Knowledge, London.

Higham, M.M., 1941, Torches for teachers. Stories, anecdotes, and facts illustrating the Church's teaching, Society for Promoting Christian Knowledge, London.

Hodgson, J., 1986, Field trip to the Manche Masemola celebrations, Sekhukhuneland sine loco (s.I).

Kgopelo, P., 2017, 'Homecoming of Kgoshi Mampuru II and St Manche Masemola', Sekhukhune News, viewed 27 September 2019, from http://www. sekhukhunedistrict.gov.za/sdm-admin/documents/April\%202017\%20 External\%20Newletter\%201.pdf.

Kuzwayo, M., 2013, 'A church and culture exploration of the Ga-Marishane village rite of initiation in contestation with the Anglican Initiation Rite of Baptism of adults: A Manche Masemola case study', Master's degree in biblical and historical studies, The University of KwaZulu-Natal, Durban.

Manyaka, P., 2017, 'Martyress Manche Masemola stage play set to hit Marble Hall', Greater Tubatse News, viewed 10 September 2019, from http:// greatertubatsenews.co.za/2017/11/23/matyress-manche-masemola-stage-playset-to-hit-marble-hall/.
Masenya, M., 2017a, Masemola, Manche, (B), 1913-1928, Anglican Communion South Africa, Dictionary of African Christian Biography, viewed 28 December 2018, from https://dacb.org/stories/southafrica/masemola-manche2/.

Masenya, M., 2017b, 'Manche Masemola and Albert Luthuli: Iconic figures of South African Christianity', Journal of African Christian Biography 2(4), 14-28, viewed 10 June 2020, from https://dacb.org/resources/journal/2-4/2-4-Oct2017JACBbooklet.pdf/.

Merriam-Webster Dictionary, 2009, Martyr, viewed 10 September 2019, from https:// www.merriam-webster.com/dictionary/martyr.

Mokgoatšana, S., 2019a, 'Controversial contradictions in testimonies about Manche Masemola: The challenge of variability in oral history', paper read at the OHASA Annual Oral History Conference, Middleburg, 7-11 October 2019.

Mokgoatšana, S., 2019b, 'Of Jane and Manche: Of Jane and Manche: Bodies and virginity as agency for narrative discourse', unpublished paper read at the University of Limpopo Spring Lectures 2019, Sovenga.

Mokgoatšana, S., 2019c, 'Of prophecy, mythmaking, and martyrdom in Manche Masemola narrative: "I will be baptised in my blood"', Studia Historiae Ecclesiasticae 45(2).

Parker, W., 1937, 1883-1966 (Bp. of Pretoria 1933-1950), The death of Manche Manche Masemola, 2I.Ts. AB393f. Wits Historical Papers. [A1][A2].

Smith, K. \& Doniger, W., 1989, 'Sacrifice and substitution: Ritual mystification and mythical demystification', Numen 36(2), 189-224. https://doi.org/10.1163/ $156852789 \times 00045$

Westminster Abbey, 2019, Manche Masemola, viewed 25 September 2019, from https://www.westminster-abbey.org/abbey-commemorations/commemorations/ manche-masemola.

Wikipedia, 2020, Martyr, viewed 02 August 2020, from https://en.wikipedia.org/wiki/ Martyr.

Winstead, K.A., 2005, 'Fear in late-medieval English Martyr legend', in J. Leemans (ed.), More than a memory: The discourse of Martyrdom and the construction of Christian identity in the history of Christianity, pp. 201-220, Uitgeverij Peeters, Leuven. 